\title{
Examining the Relevance of Emotional Intelligence and Organizational Commitment among Employees of Small and Medium Enterprise in Private Sector
}

\author{
Ashkan Khalili \\ Faculty of Management, Multimedia University \\ Jalan Multimedia, Cyberjaya 63100, Selangor, Malaysia \\ E-mail: ashkankhalili@ymail.com
}

Received: June 14, 2011

Accepted: July 29, 2011 Published: December 1, 2011

doi:10.5539/ijbm.v6n12p180

URL: http://dx.doi.org/10.5539/ijbm.v6n12p180

\begin{abstract}
The relevance of emotional intelligence and organizational commitment is tested among 142 employees of small and medium enterprise (SME) in private sector in Iran. The results indicate that there is a significant relationship between emotional intelligence as an overall construct and organizational commitment. Strong and positive influence of self management and social awareness as two competencies of emotional intelligence on employees' obligation to the organization is found. Meanwhile, positive but not significant impact of self awareness and relationship management as two abilities of emotional intelligence on employees' organizational commitment is educated. Therefore, due to lack of financial resources and support for private sector organizations in Iran, the results have a great implication for SMEs in private sector to prevent from wasting their financial resources by hiring individuals who are more emotionally intelligence that would result in higher level of organizational commitment.
\end{abstract}

Keywords: Emotional intelligence, Organizational commitment, SME, Private sector

\section{Introduction}

Changes are an ongoing challenges faced by organizations to be overcome ahead of the competitors, to ensure companies gain competitive advantages. In other words, it is commonplace for firms to face changes, both internal and external the company has to adapt to these changes. Certainly, organizations need to improve their competitive advantages as well as maximize the achievement from the needed changes transformation process, to cope with their competitors. In so doing, employees in organizations should pay attention to change, and consider them seriously (Pritchett, 2004). On the other hand, reaching optimum productivity is the most considerable aim of each organization. Undoubtedly, proficient and skillful human force is one of the most important elements that help organizations to achieve their goals, because human force plays a significant role in changing the level of productivity.

Abraham and Rebecca (1999) claimed that emotionally intelligence individuals are more skilled to cope with life activities and they have productive thinking which often includes affective awareness. Initially, Mayer and Salovey presented the concept of emotional intelligence which is "the subset of social intelligence that involves the ability to monitor one's own and others' feelings and emotions, to discriminate among them and to use this information to guide one's thinking and actions" (Mayer \& Salovey, 1993). Mayer and Salovey (1993) asserted emotional intelligence is not just positive characteristic, rather it consists of logical and emotionally diverse ability and with social intelligence it considered the vital emotional issues as well as appeasing both personal and social difficulties. Individuals who are more emotionally intelligence have much more life satisfaction, partake in others emotion, and also usually are more ordered, warm, prosperous, and optimistic (Mayer, 2000; Salaski \& Gartwright, 2003). Recently, role of emotions in the workplace have started to exert positively through organizational scholars (Fineman, 1997; Domagalski, 1999; Turnbull 1999; Fisher \& Ashkanasy, 2000; Brief \& Weiss, 2002; Jordan \& Troth, 2002).

Many researches that have concentrated on emotion in workplaces have asserted that organizations are "emotional places" (Armstrong, 2000), "incubators of emotions" (Muchinsky, 2000) or "emotional arenas" (Fineman, 2000) and it always stimulates doubt and commotion (French, 2001). That is to say, few researches 
have concentrated on how emotions are experimented in the workplace (Pekrun \& Frese, 1992), comprising organization psychic pressure and stress (Fineman, 2000). Since emotions and feelings are at the core of the human experiment (Muchinsky, 2000), very nature of the "organization" of work pertain to what individuals do with their sensations (Fineman, 1993).

In accord with Bridget Murray (1998), individuals who are at the top of their field are not only good at their works. This means that, emotional intelligence (EI) takes more than intelligence quotient (IQ) to achieve success at workplace (Goleman, 1995). That is to say, besides bosses and corporate leaders, employees also need high portion of emotional intelligence, because they present the organization to the public. Cherniss (2000) found several scholars suggested that there is a positive and direct relationship between the level of emotional intelligence (EI) and workplace performance. Cooper (1997) claimed that well managed emotions can assist ones to extend trust, loyalty and commitment, with their selves, their groups and their firms.

Several studies have investigated the relationship between emotional intelligence and organizational commitment within firms in public sector. However, most researches have given little or no attention to examine this relevance in private sector especially within Small and Medium Enterprises (SMEs). Certainly, Small and Medium Enterprises (SMEs) portray a considerable role in the strategic and sustainable development of human, social and economic capital. This study is decided to understand whether employees of small and medium enterprise (SME) in private sector with higher level of emotional intelligence are more obligated to their organization or not. Thus, the research empirically objectives are divided into two categories: 1) General empirical objective: To investigate the relationship between emotional intelligence (as a whole construct) and organizational commitment among employees who are in SME in private sector of Iran. 2) Specific empirical objective: To investigate the relationship between emotional intelligence competencies (Self-awareness, Self-management, Social awareness and Relationship management) and organizational commitment among employees who are within SME in private sector of Iran.

\section{Literature Review}

\subsection{Emotional Intelligence (EI)}

Scholars considered emotional intelligence as a factor which consists of positive attitudes, behaviors and outcomes. Testimony revealed that emotional intelligence can be conceptualized as both ability (Ciarrochi et al. 2000) and a personality character (Schutte \& Malouff, 1999). Bar-On et al. (2000) defined emotional intelligence as an array of emotional, personal and social abilities and skills that impact individual's ability to challenge and cope with environmental pressures and demands in effective ways. Undoubtedly, they perceived emotional intelligence as a non cognitive intelligent. According to Salovey and Mayer (1989-1990) definition, emotional intelligence is "the subset of social intelligence that involves the ability to monitor one's own and others' feelings and emotions, to discriminate among them and to use this information to guide one's thinking and actions". That is to say, they refined definition of emotional intelligence as "the ability to perceive emotions, to access and generate emotions so as to assist thoughts, to understand emotions and emotional knowledge, and to reflectively regulate emotions so as to promote emotional and intellectual growth" (Mayer \& Salovey, 1997).

Van Maanen and Kunda (1989) stated emotions as "ineffable feelings of the self-referential sort" and are defined as "self-referential feeling an actor (employee) experiences or, at least, claims to experience in regard to the performances he or she brings off in the social world". States of feeling which mentioned is consisted of basic emotions such as joy, love and anger, as well as social emotions such as shame, guilt, jealousy and envy. In other word, it constructs affect mood and sentiments (Ashforth \& Humphrey, 1995).

Research has shown that emotional intelligence is the prevalent element that impacts the different ways in which people develop in their lives, jobs, social skills, handling frustration and controlling emotions to be friendly toward with other people. For instance, it has been found that due to person's emotional intelligence there is a difference between a brilliant manager and simply brilliant person. As a matter of fact, emotional intelligence dictates the way people deal with others and understand emotions. Therefore, emotional intelligence is indispensable for business leaders because if they are insensitive to the mood of their staff or team, they cannot handle frustration, hence, not achieve the best out of people (Anonymous, 2004).

Thus, the ability of identifying, using, understanding and managing your emotions in positive and constructive ways is emotional intelligence. It is about discerning individual's own and others emotional states. Also, it is referred to the ability that makes it possible to engage with others in ways that draw people to you.

\subsection{Organizational Commitment (OC)}

Indeed due to the huge amount of researches that conducted to assess the relationship among organizational commitment, behavior and attitudes in the workplace (Porter et al., 1974; Koch \& Steers, 1978; Angle \& Perry, 1981), organizational commitment (OC) is one of the most considerable places in the study of organizational 
behavior and organizational psychology to predict a various of organizational outcomes as well as specifying organizational effectiveness behavior (Mathieu \& Zajac, 1990; Meyer\& Allen, 1997; Meyer, Stanley, Herscovitch, \& Topolnytsky, 2002; Sinha \& Jain, 2004). A diverse of prior and outcomes of organizational commitment such as diminishing turnover, lowering absenteeism, increasing organizational citizenship behavior and job performance have been identified in the past thirty years (Mathieu \& Zajac, 1990, Angle \& Perry, 1981; Mowday et al., 1979; Hall, 1977).

Meyer and Allen believed that organizational commitment is a multidimensional construct. They compromised organizational commitment into three components: affective commitment, continuance commitment and normative commitment (Meyer \& Allen, 1991; Dunham et al., 1994). Affective commitment is identified as "the emotional attachment, identification, and involvement that an employee has with its organization and goals" (Mowday et al., 1979; Meyer, Allen \& Smith, 1993; O’Reily \& Chatman, 1986). Continuance commitment is about employees' "nontransferable" investments (such as retirement, relationships with other employees, or things that are special to the organization) in an organization which results from their desire through remaining within an enterprise (Reichers, 1985). Normative commitment is a partly new phrase of organizational commitment which describes individuals' obligation to their workplace or commitment that they have to the organization (Bolon, 1997).

\subsection{Emotional Intelligence (EI) and Organizational Commitment (OC)}

A growing body of organizational and occupational study point more generally to the considerable role of emotional intelligence at workplace. Emotional intelligence is associated with greater work satisfaction, increased ability to deal with stress, a better change orientation or propensity and stronger organizational commitment (Carmeli, 2003; Vakola et al., 2004).

Zeidner et al. (2004) suggested that more emotionally intelligence individuals presumably succeed in communicating their ideas, goals and purposes in interesting and forceful ways (Goleman, 1998), emotional intelligence may be related to the social skills needed for teamwork (Mayer \& Salovey, 1997), organizational leaders who are emotionally intelligence may influence the relationship in the work setting, which, in order, impacts group and ones' emotional intelligence and organizational commitment (Cherniss, 2001), and at last, emotional intelligence is asserted to affect individual's skill to succeed in coping with environmental demands and pressures, clearly a significant set of behaviors to harness under stressful work conditions (Bar-On, 1997). Goleman (1995) defined emotional intelligence (EI) as the ability to be conscious of emotions in self as well others to manage the emotions in self and others. He also asserted emotional intelligence (EI) has weighty impact on one's personally and professionally success in life in compare with cognitive intelligence.

Several studies have established a positive relationship among emotional intelligence and organizational commitment. Nonetheless, in Iran, the lack of research on appraising the relationship between employees' emotional intelligence and organizational commitment within Small and Medium Enterprise (SME) especially in private sector is perceived.

\section{Methodology}

\subsection{Research Design}

This is an explanatory correlation research that uses the survey method with the purpose to collect information of variables and to measure all variables quantitatively. After identifying the sample, questionnaires are distributed to the employees who are in LAR Consulting Engineers (LCE) Company which is small and medium enterprise (SME) in private sector in Iran. Then all the collected data are analyzed to find out whether the result of the analysis can support the explanation of the research objectives or not.

\subsection{Theoretical Framework}

As discussed earlier, this research is examined the relationship between emotional intelligence and organizational commitment. In this section, a research theoretical framework (Figure 1) of the factors influencing organizational commitment is developed based on the empirical objectives. This framework (Figure 1) is developed in accord with Goleman's refinement model of emotional intelligence (2001) as well as Allen and Meyer (1990) organizational commitment model, which examines the relationship of several emotional intelligence competencies (self-awareness, self-management, social awareness and relationship management) as independent variables to organizational commitment as a dependent variable.

\subsection{Variables and Demographic Factors for the Study}

According to the recent studies, there are many factors influencing employee's organizational commitment. There are also many dimensions of emotional intelligence base on previous researches. This study examines the relationship between emotional intelligence and organizational commitment. Therefore, the variables that are 
utilized in this research defined in Table 1. They encompass emotional intelligence (self-awareness, self-management, social awareness and relationship management), organizational commitment (affective commitment, continuance commitment and normative commitment). Some factors such as gender, age and educational level are considered as demographic factors in this study.

\subsection{Hypothesis Development}

Organizational leaders with high levels of emotional intelligence (EI) may influence the relationship in the work setting, which, in turn, affects group and individual emotional intelligence and organizational commitment (OC) (Cherniss, 2001). Studies have shown the impact of emotional intelligence (EI) on organizational commitment (OC), culture, climate and employee performance (Goleman et al. 2002). Kets de Vries and Miller (1984) illustrated that organizational success and failure can be determined by the emotional tone set by the executive or presumed leader of a firm. Therefore, emotional intelligence can be conceptualized as collateral for developing commitment within organizations. Based on the theoretical framework, four sub-hypotheses and one main research hypothesis are formulated as below:

Sub-hypotheses:

H1: There is a significant relationship between self-awareness and organizational commitment of employees.

$\mathrm{H} 2$ : There is a significant relationship between self-management and organizational commitment of employees.

H3: There is a significant relationship between social awareness and organizational commitment of employees.

H4: There is a significant relationship between relationship management and organizational commitment of employees.

Main hypothesis:

H5: There is a significant relationship between emotional intelligence and organizational commitment of employees.

\subsection{Questionnaire Design}

A structured questionnaire is used as a research instrument in this study. The questionnaire comprises three sections. Section A solicits general information from the respondents namely gender, age, and education level. In accordance with Bradberry and Greaves (2003) who developed standard questionnaire for emotional intelligence based on Goleman's four competencies of emotional intelligence, section B consists of 28 statements and is used to solicit the information pertaining to emotional intelligence namely self-awareness, self-management, social awareness and relationship management.

According to the Allen and Meyer (1990) that developed questionnaire for organizational commitment construct, section $\mathrm{C}$ consists of 12 statements. Section $\mathrm{C}$ solicits information pertaining to the respondent's organizational commitment namely affective commitment, continuance commitment and normative commitment.

The determinants of emotional intelligence and the statements measuring them are presented in Table 2. In this table, statements from 1 to 6 illustrate respondent's Self-Awareness competency, statements from 7 to 15 assess respondent's Self-Management ability, statements from 16 to 20 examine respondent's Social Awareness competency, while statements 21 to 28 appraise respondent's Relationship Management ability. The respondents are requested to indicate the extent that each statement characterized them using the Likert scale format from 1 (Never) to 6 (Always) as shown in Figure 2.

In Table 3, statements from 1 to 3 illustrate respondent's affective commitment, statements from 4 to 7 estimate respondent's continuance commitment, while statements 8 to 12 appraise respondent's normative commitment. The respondents are requested to indicate the extent that each statement characterized them using the five Likert scale format from 1 (Strongly disagree) to 5 (Strongly agree) as shown in Figure 3. In this scale, one negatively item (question 12) is reverse coded.

\subsection{Sampling Procedure}

As mentioned earlier, a questionnaire is used for the purpose of collecting the primary data for this study. In order to understand the influence of emotional intelligence on organizational commitment among employees in small and medium enterprise in private sector in Iran, LAR Consulting Engineers (LCE) Company is selected. Base on convenience sampling, a total of 150 questionnaires are distributed. 142 completed questionnaires are received that representing a response rate of $94.6 \%$.

\subsection{Pilot Study to Test the Reliability and Validity of Questionnaire}

The Cronbach Alpha method is used to determine the reliability of each of the 6 constructs: self-awareness, self-management, social awareness, relationship management, overall emotional intelligence and organizational 
commitment which make up the research instrument. The Cronbach Alpha method determines the inter-item correlation among the items measuring the construct. As illustrates in Table 4 the Cronbach Alpha value ranges from 0.774 to 0.814 . As the Cronbach Alpha in this study is within the acceptable range, the constructs are therefore deemed to have adequate reliability and ready for actual survey. For this research, the reliability test is conducted while the validity test is not indispensable because the instruments are fully-adopted for this study.

\subsection{Method of Analysis}

Analysis is performed by using Statistical Packages of the Social Science (SPSS). Descriptive statistics is used to describe the profile of the respondents. Inferential statistics in the form or Pearson Product Moment Correlation is used to determine the relationship between independent variables and organizational commitment. Stepwise multiple regression analysis is used to determine which among the independent variables are correlated significantly with dependent variable (organizational commitment) and are the significant predictors. The level of significance is set at $\mathrm{p}=0.05$.

\section{Data Analysis}

\subsection{Demographics of the Sample}

As presents in Table 5 (Distribution of the Respondents According to Gender), of 142 respondents in this study, $86(60.6 \%)$ respondents are male and the remainder $56(39.4 \%)$ are female. The distribution of the respondents according to their age group is presented in Table 6 (Distribution of the Respondents According to Age). 52.1\% of respondents are between $15-35$ years old; $34.5 \%$ of respondents are between $35-55$ years old; $13.4 \%$ of respondents are more than 55 years old. As presents in Table 7 (Distribution of the Respondents According to Level of Education), $32(22.5 \%)$ respondents in this study have diploma, $10(7.0 \%)$ of them have associated diploma, 46 (32.4\%) respondents have bachelor degree, 47 (33.1\%) with master degree and 7 (4.9\%) respondents have $\mathrm{PhD}$. The majority of the respondents have master and bachelor degree respectively.

\subsection{Perception of Factors Influencing Organizational Commitment}

Descriptive analysis in the form of mean and standard deviation for the factors influencing organizational commitment is presented in Table 8. Since the rating scale is Likert scale for emotional intelligence competencies ranging from 1 to 6 with 1 meaning never and 6 meaning always, the value of 3.5 represents the mean or average score. Mean value of more than 3.5 can be regarded as indicating a strong level of competencies by the respondents.

In so doing, respondents indicate a higher level of abilities in their emotional intelligence (Table 8). That is to say, through four competencies of emotional intelligence respondents indicate much more tendency of self awareness (mean=4.37; S.D $=5.60$ ), relationship management (mean=4.22; $S . D=6.30$ ), social awareness (mean=4.11; S.D=5.95), and self management (mean=3.81; $\mathrm{S} . \mathrm{D}=5.11$ ) respectively.

\subsection{Analyzing of the Factors Influencing Organizational Commitment}

Pearson product moment correlation is used to ascertain the pattern of relationship between all the independent variables and dependent variable. The results (Table 9) reveal that self management $(r=0.211, p<0.05$ ), social awareness $(r=0.385, p<0.05)$, and emotional intelligence $(r=0.151, p<0.05)$ have significant positive relationship with organizational commitment. Based on the findings of this research, self awareness $(r=0.010$, $\mathrm{p}>0.05)$ and relationship management $(\mathrm{r}=0.043, \mathrm{p}>0.05)$ have positive relationship with organizational commitment, but they are not significant.

The significant positive relationship between self management $(r=0.211, p<0.05)$ and organizational commitment implies that self management competency such as, "emotional self-control", "transparency", "adaptability", "achievement", "initiative" and "optimism" (Goleman, 2001), could contribute to higher organizational commitment among employees working in the organization. Therefore, sub hypothesis 2, that is "There is a significant relationship between self-management and organizational commitment of employees" is accepted (Table 10).

The results also show that social awareness $(\mathrm{r}=0.385, \mathrm{p}<0.05)$ ability such as, "empathy", "organizational awareness" and "service" (Goleman, 2001), is positively related to organizational commitment. This means that sub hypothesis 3, that is, "There is a significant relationship between social awareness and organizational commitment of employees" is accepted (Table 10).

From the correlation results of Table 9, emotional intelligence $(r=0.151, p<0.05)$ is positively related to organizational commitment, which means that, emotional intelligence as an overall construct may contribute to higher level of organizational commitment among employees. Therefore main hypothesis 5 , namely "There is a significant relationship between emotional intelligence and organizational commitment of employees" is accepted (Table 10). 
While the results indicate that self awareness $(r=0.010, p>0.05)$ competency such as, "emotional self-awareness", "accurate self-assessment" and "self-confidence" (Goleman, 2001), has positive relationship with employees obligation to the organization, but it is not significant. Therefore, sub hypothesis 1, that is, "There is a significant relationship between self-awareness and organizational commitment of employees" is rejected (Table 10). The result means that self-awareness does not influence employees organizational commitment appropriately.

Finally, it is found that relationship management $(\mathrm{r}=0.043, \mathrm{p}>0.05)$ ability such as, "inspirational leadership", " influence", "developing others", "change catalyst", "conflict management", "building bonds and teamwork" and "collaboration" (Goleman, 2001), has a correlation with employees organizational commitment but this positive relationship is not significant. Thus, sub hypothesis 4 , that is "There is a significant relationship between relationship management and organizational commitment of employees" is rejected (Table 10).

\subsection{Predictors of Organizational Commitment}

Multiple regression analysis is carried out with the variables which are correlated significantly with organizational commitment. The R-square value $=0.758$ (Table 11$)$. This means $75.8 \%$ of organizational commitment can be explained by (or can be accounted for) four competencies of emotional intelligence and emotional intelligence as an overall construct influences organizational commitment at the workplace.

Table 12 presents the results of Stepwise Regression Analysis that is carried out to determine significant predictors of commitment in the organization. The results show that there are three important predictors of commitment in the organization. Social awareness alone explains $57.6 \%$ of the variation in organizational commitment. Continuously, the fusion of social awareness and social management explain $73.7 \%$ of the variation in organizational commitment. Social awareness, social management and an overall emotional intelligence together explain $75.4 \%$ of the variation in organizational commitment.

\section{Conclusion, Discussion and Suggestions}

In this study, the findings show that emotional intelligence and organizational commitment are correlated for employees in small and medium enterprise in private sector in Iran. Emotional intelligence is significant as it is related to satisfaction, performance, and retention (Law et al., 2004) while organizational commitment is allied with whether and for what reason individuals stay with a firm (Meyer \& Allen, 1997).

Substantial research has been conducted to establish the link between emotional intelligence and job satisfaction (Dong \& Howard, 2006; Quoidbach \& Hansenne, 2009) and much evidence exists naming job satisfaction as an antecedent of organizational commitment (Lok \& Crawford, 2001; Humphreys et al., 2005; Rayton, 2006). However, there is a lack of research on the relevance of emotional intelligence and organizational commitment within small and medium enterprises that are in private sector.

Descriptive and inferential statistical analyses are conducted to test hypotheses associated with the following research objectives:

1) To investigate the relationship between emotional intelligence as a whole construct and organizational commitment among employees in small and medium enterprise (SME) in private sector.

2) To investigate the relationship between emotional intelligence competencies (Self-awareness, Self-management, Social awareness and Relationship management) and organizational commitment among employees who are in SME in private sector.

In this research, statistical evidence indicates that: 1) overall emotional intelligence has statistically positive and significant influence on organizational commitment 2) self management and social awareness from four competencies of emotional intelligence have significant positive impact on organizational commitment 3) self awareness and relationship management have positive relationship with organizational commitment, but not significant. According to the first statistical evidence there is a significant influence of an overall emotional intelligence on organizational commitment, and employees who have more emotional intelligence are more committed to the organization, hence, emotional intelligence is one of the most important factors that must be measured within organizations especially when firms need to evaluate strengths and weaknesses of workforce in response to change.

While employees' emotional intelligence impact positively on their obligation to an organization, it is necessary to investigate the benefits of educating emotional intelligence competencies within a firm. In so doing, some of the human resource strategies must focus on training employees to control and increase their emotional intelligence abilities.

Based on the second statistical evidence of this study that shows the positive and also significant influence of self management and social awareness on employees' obligation to the organization, this research concludes that 
individuals with higher level of self management and social awareness are more committed rather than employees with lower levels in these two competencies. Therefore, who are within human resource department must explore the possibility of providing training on these aspects of emotional intelligence. Indeed training employees to have higher level of, "emotional self-control", "transparency", "adaptability", "achievement", "initiative" and "optimism" (Goleman, 2001) result in much higher level of self management. On the other hand, training employees on "empathy", "organizational awareness" and "service" (Goleman, 2001) assist them to reach higher level of social awareness.

Findings show that employees who have higher level of self awareness and also relationship management competencies are more likely to be committed to the organization. While the impact of self awareness and relationship management are not significant, the emergence of training is needed within firms. Self awareness may be raised by increasing employees' "emotional self-awareness", "accurate self-assessment" and "self-confidence" (Goleman, 2001), while relationship management ability can be raised namely by fostering relationships of employees with others through "formal and informal teamwork" and "collaboration" (Goleman, 2001), which result in increasing their emotions, feelings and commitments for the organization.

The findings from this study reinforce the need for continued exploration of employees' emotional intelligence impact on their organizational commitment, especially employees in private sector. It is hoped that the research findings contribute to the knowledge of emotional intelligence and organizational commitment, and stimulate more questions than are answered in this manuscript.

Future study needs to continue to investigate the three foundational constructs of emotional intelligence exhibited by Mayer and Salovey (1997), Goleman (1995, 1998), and Bar-On (1997). Mayer and Salovey presented emotional intelligence as a purely cognitive model, while Goleman and Bar-On presented emotional intelligence as a mixed model that consists of personality competencies along with cognitive aspects.

In this research specific statistical sample and three demographic factors are chosen (gender, age and educational level), while upcoming studies can be done by testing multiple populations along with occupation, ethnicity, gender, age, and also among various levels within organizations. For instance, it is suggested that this research replicates with a larger sample size and in other settings. It would be interesting to explore if a larger sample size would result in any different statistically significant results for the relevance of emotional intelligence and organizational commitment hypotheses pose in this study.

Another significant activity would be the evaluation of the relevance of these two constructs (emotional intelligence and organizational commitment) through cross-cultural appraisal to generate more reliable findings by comparing, for instance, between two or more countries with different cultural aspects.

Meanwhile, it is recommended that the concept explores by evaluating other areas such as the influence of leader's emotional intelligence on follower's organizational commitment. In so doing, these are some potential study questions for future scholars to consider for further research:

1) Do followers of leaders with higher scores in emotional intelligence competencies have higher organizational commitment scores in small and medium enterprises that are in private sector?

2) Do followers of leaders with higher scores in emotional intelligence competencies have higher organizational commitment scores in other small and medium enterprises which are in private sector industries (technology-based, human service, etc.)?

Next recommendation concerns the research design. Further research can use a mixed method, namely coupling qualitative and quantitative methods that may improve the findings.

Continued exploration on individuals' different level of organizational commitment would be useful for private sector enterprises in Iran. Clearly, due to lack of financial resources and support for private sector organizations in Iran, hiring employees with higher level of obligation would result in having individuals who are more obligated to organization's goals thus preventing wastage of financial resources.

Additional information is needed on how commitment can be increased and how firms can utilize this knowledge to reduce turnover rates in small and medium enterprises. For example, is there a difference in obligation among full-time and part-time employees in small and medium enterprises in private sector? If so, in what way firms can benefit by concentrating on training and retention based on employment types? Likewise, would various level of emotional intelligence vary for these individuals (full-time and part-time employees), and can firms use emotional intelligence measures to predict these differences and utilize the information for selection objectives?

Since this study is a cross sectional investigation future research should focus on longitudinal influences of emotional intelligence on organizational commitment. Since organizational commitment construct is understood 
to represent a more tenuous state, it will be significant to focus on emotional intelligence impact from a longitudinal perspective.

\section{References}

Abraham \& Rebecca. (1999). Emotional intelligence in organizations: A conceptualization. Genetic, Social and General Psychology Monographs, 125(2), 209-224.

Allen, N. J., \& Meyer, J. P. (1990). The measurement and antecedents of affective, continuance and normative commitment to the organization. Journal of Occupational Psychology, 63, 1-18.

Angle, H. L., \& Perry, J. L. (1981). An empirical assessment of organization commitment and organizational effectiveness. Administrative Science Quarterly, 26, 1-13.

Anonymous. (2004). Maternal depression and child development. Pediatrics \& Child Health, 9(8), 575-583.

Armstrong, D. (2000). Emotions in Organizations. Paper presented ISPSO Symposium. London.

Ashforth, B., \& Humphrey, R. (1995). Emotion in the workplace: A reappraisal. Human Relations, 48, 97-125.

Bar-On, R. (1997). Bar-On Emotional Quotient Inventory (EQ-i): Technical manual. Toronto: Multi-Health System.

Bar-On, F., Brown, J. M., Kirkcaldy, B., \& Thome, E. (2000). Emotional expression and implications for occupational stress; an application of the Emotional Quotient Inventory (EQ-I). Personality and Individual Differences, 28, 1107-1118.

Bolon, D.S. (1997). Organizational Citizenship Behavior Among Hospital Employees: A Multidimensional Analysis Involving job Satisfaction and Organizational Commitment. Hospital \& Health Services Administration, 42(2), 221-241.

Bradberry, T.R., \& Greaves, J.M. (2003). The Emotional Intelligence Appraisal тм Technical Manual. San Diego: TalentSmart, Inc.

Bridget Murray. (1998). The APA Monitor, 29, 7, 3-4.

Brief, A. P., \& Weiss, H. (2002). Organizational behavior: Affect in the workplace. Annual Review of Psychology, 53, 279-307.

Carmeli, A. (2003). The relationship between emotional intelligence and work attitudes, behavior and outcomes: An examination among senior managers. Journal of Managerial Psychology, 18(8), 788-813, http://dx.doi.org/10.1108/02683940310511881

Cherniss, C., \& Adler, M. (2000). Promoting emotional intelligence in organizations: Make training in emotional intelligence effective. Alexandria, VA: American Society for Training and Development.

Cherniss, C. (2001). Emotional intelligence and organizational effectiveness. In Cherniss, C., \& Goleman, D. (Eds.), The emotionally intelligent workplace: How to select for, measure, and improve emotional intelligence in individuals, groups, and organizations, (pp. 3-12). San Francisco: Jossey-Bass.

Ciarrochi, J. V., Chan, A. Y. C., \& Caputi, P. (2000). A critical evaluation of the emotional intelligence construct. Personality and Individual Differences, 28, 539-561. http://dx.doi.org/10.1016/S0191-8869(99)00119-1

Cooper, R.K., \& Sawaf, A. (1997). Executive eq: Emotional intelligence in leadership and organizations. New York, NY: Berkley Publishing Group.

Domagalski, T.A. (1999). Emotion in organizations. Human Relations, 52(6), 833-852. http://dx.doi.org/10.1177/001872679905200607

Dong, Q., \& Howard, T. (2006). Emotional intelligence, trust, and job satisfaction. Competition Forum, 4, 381-388.

Dunham, R.B., Grube, J.A., \& Castenada, M.B. (1994). Organizational commitment: The utility of an integrative definition. Journal of Applied Psychology, 79(3), 370-380. http://dx.doi.org/10.1037//0021-9010.79.3.370

Fineman, S. (1993). Emotion in organizations, (Ed.). London: Sage Publications.

Fineman, S. (1997). Emotion and management learning. Management Learning, 28(1), 13-25. http://dx.doi.org/10.1177/1350507697281002

Fineman, S. (2000). Emotions in organizations. (2nd ed). Thousand Oaks, CA: Sage.

Fisher, C. D., \& Ashkanasy, N. M. (2000). Emotions in organizations. Journal of Organizational Behavior, 21, $121-234$ 
French, R. (2001). Negative Capability": managing the confusing uncertainties of change. Journal of Organizational Change Management, 14(5), 480-492. http://dx.doi.org/10.1108/EUM0000000005876

Goleman, D. (1995). Emotional intelligence. New York: Bantam Books.

Goleman, D. (1998). What makes a leader? Harvard Business Review, 76(6), 93-102.

Goleman, D. (2001). An EI-based theory of performance. In C. Cherniss \& D. Goleman (Eds.), The Emotionally Intelligent Workplace. San Francisco: Jossey-Bass.

Goleman, D., Boyatzis, R., \& McKee, A. (2002). Primal Leadership: Realizing the Power of Emotional Intelligence. Boston: HBS Press.

Hall, D. (1977). Organizational identification as a function of career pattern and organizational type. Administrative Science Quarterly, 17(3), 340-350. http://dx.doi.org/10.2307/2392147

Heppner, P. P., Kivlighan, D. M., \& Wampold, B. E. (1999). Research design in counseling. (2nd ed.). Belmont, CA: Wadsworth.

Humphreys, J., Brunsen, B., \& Davis, D. (2005). Emotional structure and commitment: Implications for health care management. Journal of Health Organization and Management, 19, 120-129, http://dx.doi.org/10.1108/14777260510600040

Jordan, PJ., \& Troth, AC. (2002). Emotional intelligence and conflict resolution: Implications for human resource development, in JL Callahan \& EE McCollum (eds.), Advances In Developing Human Resources, Special Edition Perspectives of Emotion and Organizational Change, 4 (1), 62-79.

Kets de Vries, M. F. R., \& Miller, D. (1984). The Neurotic Organization. San Francisco, CA: Jossey-Bass.

Koch, J., \& Steers, R. (1978). Job attachment, satisfaction, and turnover among public sector employees. Journal of Vocational Behavior, 12(1), 119-128. http://dx.doi.org/10.1016/0001-8791(78)90013-1

Law, K. S., Wong, C. S., \& Song, L. J. (2004). The construct and criterion validity of emotional intelligence and its potential utility for management studies. Journal of Applied Psychology, 89(3), 483-496. http://dx.doi.org/10.1037/0021-9010.89.3.483

Lok, P., \& Crawford, J. (2001). Antecedents of organizational commitment and the mediating role of job satisfaction. Journal of Managerial Psychology, 16(8), 594-613. http://dx.doi.org/10.1108/EUM0000000006302

Mathieu, J. E., \& Zajac, D. M. (1990). A review and meta-analysis of the antecedents, correlates and consequences of organizational commitment. Psychological Bulletin, 108(2), 171-194. http://dx.doi.org/10.1037//0033-2909.108.2.171

Mayer, J. D. (2000). Emotion, intelligence, emotional intelligence. InJ. P. Forgas (Ed.), The handbook of affect and social cognition, (pp.410-431). Mahwah, NJ: Lawrence Erlbaum Associates, Inc.

Mayer, J. D., \& Salovey, P. (1993). The intelligence of emotional intelligence. Intelligence, 17, 433-442.

Mayer, J. D., \& Salovey, P. (1997). What is emotional intelligence? In I. P. Salovey \& D. J. Sluyter (Eds.), Emotional Development and Emotional Intelligence (pp. 3-13). New York: Basic Books.

Meyer, J. P., Allen, N. J., \& Smith, C. A. (1993). Commitment to Organizations and Occupations: Extension and Test of a Three-Component Conceptualization. Journal of Applied Psychology, 78(4), 538-552. http://dx.doi.org/10.1037//0021-9010.78.4.538

Meyer, J. R., \& Allen, N. J. (1991). A three-component conceptualization of organizational commitment. Human Resource Management Review, 1(1), 61-89. http://dx.doi.org/10.1016/1053-4822(91)90011-Z

Meyer, J.P., \& Allen, N.J. (1997). Commitment in the Workplace: Theory, Research, and Application. Thousand Oaks, CA: Sage Publications.

Meyer, P. J., Stanley, D. J., Herscovitch, L., \& Topolnytsky, L. (2002). Affective, continuance, and normative commitment to the organization: A meta-analysis of antecedents, correlates, and consequences. Journal of Vocational Behavior, 61(1), 20-52. http://dx.doi.org/10.1006/jvbe.2001.1842

Mowday, R., Porter, L., \& Steers, R. (1979). The measurement of organizational commitment. Journal of Vocational Behavior, 14(2), 224-247. http://dx.doi.org/10.1016/0001-8791(79)90072-1

Muchinsky, P. M. (2000). Emotions in the workplace: The neglect of organizational behavior. Journal of Organizational Behavior, 21(7),

http://dx.doi.org/10.1002/1099-1379(200011)21:7<801::AID-JOB999>3.3.CO;2-1 
O'Reilly, C. A., \& Chatman, J. (1986). Organizational commitment and psychological attachment: The effects of compliance, identification and internalization on pro social behavior. Journal of Applied Psychology, 71, 492-499.

Pekrun, R., \& Frese, M. (1992). Emotions in work and achievement, In: Cooper, C. L. and Robertson, D. T. (Eds), International Review of Industrial and Organizational Psychology, 7, (pp. 153-200). St. Edmundsbury Press, John Wiley \& Sons Ltd., Chichester.

Porter, L. W., Steers, R. M., Mowday, R. T., \& Boulian, P. V. (1974). Organizational commitment, job satisfaction, and turnover among psychiatric technicians. Journal of Applied Psychology, 59(5), 603-609. http://dx.doi.org/10.1037/h0037335

Pritchett, P. (2004), Culture Shift, Pritchett/Rummler-Brache, Dallas, TX.

Quoidbach, J., \& Hansenne, M. (2009). The impact of trait emotional intelligence on nursing team performance and cohesiveness. Journal of Professional Nursing, 25(1), 23-29. http://dx.doi.org/10.1016/j.profnurs.2007.12.002

Rayton, B.A. (2006). Examining the interception of job satisfaction and organizational commitment: an application of the bivariate model. International Journal of Human Resource Management, 17(13), 9-54.

Reichers, Arnon. (1985). A review and reconceptialitzion of organizational commitment. The Academy of Management Review, 10(3), 465-476.

Salaski, M., \& Gartwright, S. (2002). Health, performance and emotional intelligence: an explanatory study of retail managers, 18(2), 63-68. http://dx.doi.org/10.1002/smi.926

Salovey, P., \& Mayer, J. D. (1989-1990). Emotional intelligence. Imagination, Cognition and Personality, 9(3), 185-211. http://dx.doi.org/10.2190/DUGG-P24E-52WK-6CDG

Schutte, N.S., \& Malouff, J.M. (1999). Measuring Emotional Intelligence and Related Constructs. Edwin Mellen Press, Lewiston, New York.

Sinha, A.K., \& Jain, A.K. (2004). Emotional intelligence: Imperative for the organizationally relevant outcomes. Psychological Studies, 49, 81-96.

Turnbull, S. (1999). Emotional labour in corporate change programmes: the effect of organizational feeling rules on middle managers. Human Resources Development International, 2(2), 125-146.

Vakola, M., Tsaousis, I., \& Nikolaou, I. (2004). The effects of emotional intelligence and personality variables on attitudes toward organizational change. Journal of Managerial Psychology, 19, 88-110.

Van Maanen, J., \& Kunda, G. (1989). Real feelings: emotional expression and organizational culture. Research in Organizational Behavior, JAI Press, Greenwich, CT, 11, 43-103.

Zeidner, M., Matthews, G., \& Roberts, R. (2004). Emotional intelligence in the workplace: a critical review. Applied Psychology: An International Review, 53(3), 371-99. http://dx.doi.org/10.1111/j.1464-0597.2004.00176.x 
Table 1. Variables and Demographic Factors of Research

\begin{tabular}{|c|l|}
\hline \multicolumn{2}{|c|}{ Variables \& Demographic Factors } \\
\hline \multicolumn{3}{|c|}{ Emotional Intelligence (EI) } \\
\hline Independent Variable & \multicolumn{1}{c|}{ Construct } \\
\hline Self-Awareness & $\begin{array}{l}\text { Employee's emotional self-awareness, Accurate } \\
\text { self-assessment and Self-confidence }\end{array}$ \\
\hline Self-Management & $\begin{array}{l}\text { Employee's emotional self-control, Transparency, } \\
\text { Adaptability, Achievement, Initiative and Optimism }\end{array}$ \\
\hline Social Awareness & Employee's empathy, Organizational awareness and Service \\
\hline Relationship Management & $\begin{array}{l}\text { Employee's inspirational leadership, Influence, Developing } \\
\text { others, Change catalyst, Conflict management, Building bonds } \\
\text { and Teamwork \& collaboration }\end{array}$ \\
\hline \multicolumn{3}{|c|}{ Organstruct } \\
\hline Dependent Variable & $\begin{array}{l}\text { Employee's emotional attachment, identification, and } \\
\text { involvement that an employee with its organization and goals }\end{array}$ \\
\hline Continuance Commitment & $\begin{array}{l}\text { Employee's "nontransferable" investments in an organization } \\
\text { which result from their desire through remaining within an } \\
\text { enterprise }\end{array}$ \\
\hline Normative Commitment & $\begin{array}{l}\text { Employee's obligation to their workplace or commitment to } \\
\text { the organization }\end{array}$ \\
\hline \multicolumn{2}{|c|}{ Variables \& Demographic Factors } \\
\hline Demographic Factors & Commitment \\
\hline Gender & Male, Female \\
\hline Age & $\begin{array}{l}\text { High school diploma, Min. 2years of University Education, } \\
\text { Bachelor's Degree, Master's Degree, Doctorate Degree }\end{array}$ \\
\hline
\end{tabular}


Table 2. Measurement Items for Independent Variables




Table 3. Measurement Items for Dependent Variable



Table 4. Reliability Statistics of the Research Constructs in the Questionnaires

\begin{tabular}{|c|c|}
\hline Variables & Cronbach Alpha \\
\hline Self Awareness & 0.804 \\
\hline Self Management & 0.797 \\
\hline Social Awareness & 0.803 \\
\hline Relationship Management & 0.814 \\
\hline Emotional Intelligence & 0.813 \\
\hline Organizational Commitment & 0.774 \\
\hline
\end{tabular}

Table 5. Distribution of the Respondents According to Gender

\begin{tabular}{|c|c|c|}
\hline Gender & Frequency & Percentage \\
\hline Female & 56 & 39.4 \\
\hline Male & 86 & 60.6 \\
\hline Total & $\mathbf{1 4 2}$ & $\mathbf{1 0 0 . 0}$ \\
\hline
\end{tabular}

Table 6. Distribution of the Respondents According to Age

\begin{tabular}{|c|c|c|}
\hline Age & Frequency & Percentage \\
\hline Between $15-35$ & 74 & 52.1 \\
\hline Between $35-55$ & 49 & 34.5 \\
\hline $55+$ & 19 & 13.4 \\
\hline Total & $\mathbf{1 4 2}$ & $\mathbf{1 0 0 . 0}$ \\
\hline
\end{tabular}


Table 7. Distribution of the Respondents According to Level of Education

\begin{tabular}{|c|c|c|}
\hline Level of Education & Frequency & Percentage \\
\hline Diploma & 32 & 22.5 \\
\hline Associated diploma & 10 & 7.0 \\
\hline B.S/B.A & 46 & 32.4 \\
\hline M.S/M.A & 47 & 33.1 \\
\hline PhD & 7 & 4.9 \\
\hline Total & $\mathbf{1 4 2}$ & $\mathbf{1 0 0 . 0}$ \\
\hline
\end{tabular}

Table 8. Descriptive Statistics on the Perceived Factors Influencing Organizational Commitment

\begin{tabular}{|l|c|c|c|}
\hline \multicolumn{1}{|c|}{ Variables } & N & Mean & Std. Deviation \\
\hline 1.Emotional Intelligence & & & \\
\hline Self Awareness & 127 & 4.37 & 0.56028 \\
Self Management & 127 & 3.81 & 0.51108 \\
Social Awareness & 127 & 4.11 & 0.59541 \\
Relationship Management & 127 & 4.22 & 0.63032 \\
\hline 2.Organizational Commitment & 127 & 4.08 & 0.39655 \\
\hline
\end{tabular}

Table 9. Pearson Product Moment Correlation Analysis of the Factors Influencing Organizational Commitment

\begin{tabular}{|c|c|c|}
\hline $\begin{array}{c}\text { Factors Influencing } \\
\text { Organizational commitment }\end{array}$ & $\mathbf{r}$ & $\mathbf{P}$ \\
\hline Self Awareness & 0.010 & 0.798 \\
\hline Self Management & 0.211 & $0.000^{*}$ \\
\hline Social Awareness & 0.385 & $0.000^{*}$ \\
\hline Relationship Management & 0.043 & 0.230 \\
\hline Emotional Intelligence & 0.151 & $0.007^{*}$ \\
\hline
\end{tabular}

Note: * Significant at $\mathrm{p}=0.05$ level

Table 10. Summary of the Findings

\section{Hypotheses Statements}

\section{Sub-hypotheses}

H1: There is a significant relationship between self-awareness and organizational commitment of employees.

H2: There is a significant relationship between self-management and organizational commitment of employees.

H3: There is a significant relationship between social awareness and organizational commitment of employees.

H4: There is a significant relationship between relationship management and organizational commitment of employees.

\section{Main hypothesis}

H5: There is a significant relationship between emotional intelligence and organizational commitment of employees.

Table 11. Simple Multiple Regression of Analysis for Predictors of Organizational Commitment

\begin{tabular}{|l|l|l|l|l|l|l|l|l|l|}
\hline \multirow{2}{*}{ Model } & \multirow{2}{*}{$\mathrm{R}$} & \multirow{2}{*}{$\begin{array}{l}\mathrm{R} \\
\text { Square }\end{array}$} & $\begin{array}{l}\text { Adjusted R } \\
\text { Square }\end{array}$ & $\begin{array}{l}\text { Std. Error of } \\
\text { the Estimate }\end{array}$ & $\begin{array}{l}\text { R Square } \\
\text { Change }\end{array}$ & F Change & df1 & df2 & $\begin{array}{l}\text { Sig. F } \\
\text { Change }\end{array}$ \\
\hline 1 & & & & & & & & &
\end{tabular}

a. Predictors: (Constant), Self Awareness, Self Management, Social Awareness, Relationship Management, Emotional Intelligence

b. Dependent Variable: Organizational Commitment 
Table 12. Stepwise Multiple Regressions: Predictors of Organizational Commitment

\begin{tabular}{|l|c|c|c|c|c|c|c|c|c|}
\hline \multirow{2}{*}{ Model } & & & & & & \multicolumn{5}{|c|}{ Change Statistics } \\
\cline { 5 - 9 } & & \multirow{2}{*}{$\begin{array}{c}\mathrm{R} \\
\text { Square }\end{array}$} & $\begin{array}{c}\text { Adjusted R } \\
\text { Square }\end{array}$ & $\begin{array}{c}\text { Std. Error } \\
\text { of the } \\
\text { Estimate }\end{array}$ & $\begin{array}{c}\text { R Square } \\
\text { Change }\end{array}$ & F Change & df1 & df2 & $\begin{array}{c}\text { Sig. F } \\
\text { Change }\end{array}$ \\
\hline 1 & $.759^{\mathrm{a}}$ & .576 & .573 & .25923 & .576 & 169.852 & 1 & 125 & .000 \\
3 & $.859^{\mathrm{b}}$ & .737 & .733 & .20492 & .161 & 76.034 & 1 & 124 & .000 \\
\hline
\end{tabular}

a. Predictors: (Constant), Social Awareness

b. Predictors: (Constant), Social Awareness, Social Management

c. Predictors: (Constant), Social Awareness, Social Management, Emotional Intelligence

d. Dependent Variable: Organizational Commitment

Emotional Intelligence (EI)

- Self Awareness

- Self Management

- Social Awareness

- Relationship Management



Figure 1. Research Theoretical Framework

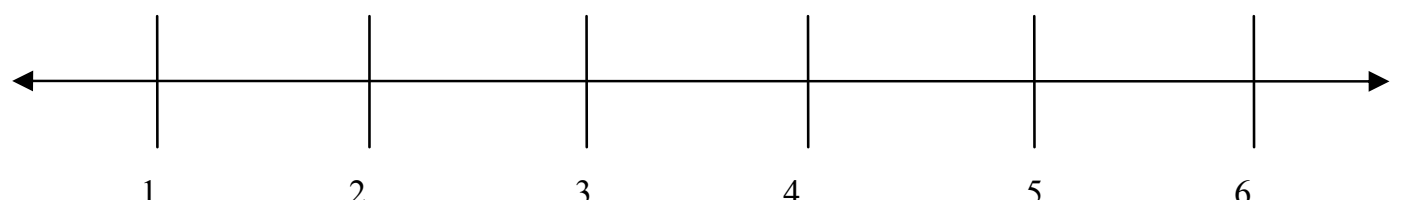

Never Rarely Sometimes Usually Almost Always Always

Figure 2. Six Likert Scale Format

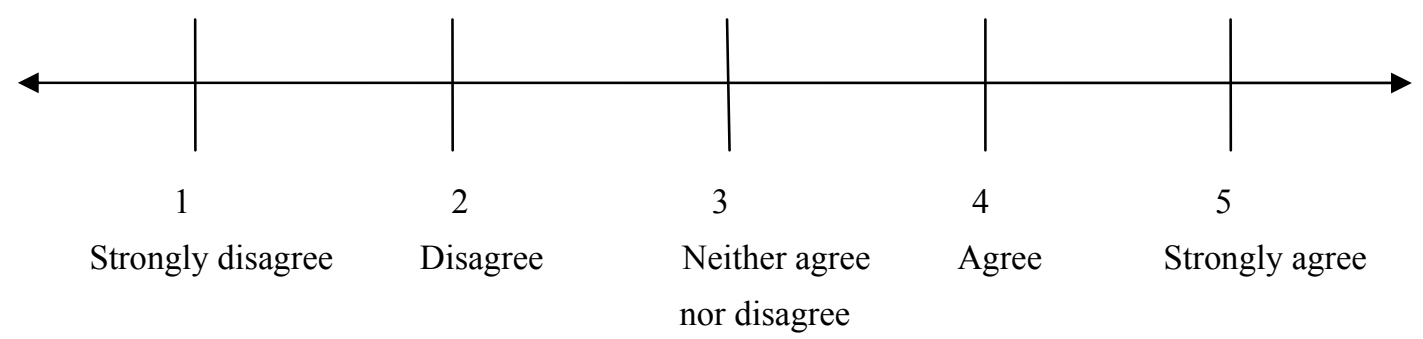

Figure 3. Five Likert Scale Format 